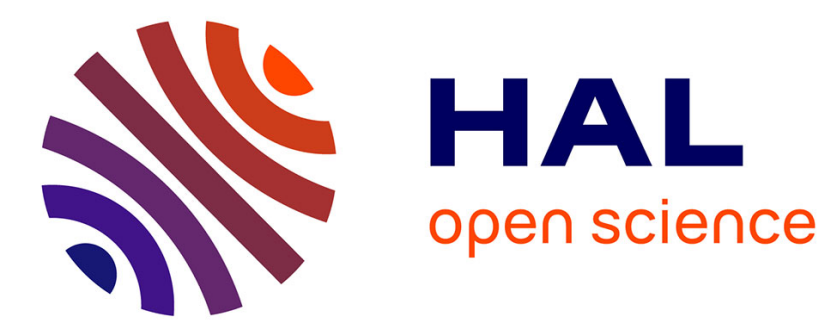

\title{
Role of goethite during air-oxidation of PAH-contaminated soils
}

Coralie Biache, Olivier Kouadio, Khalil Hanna, Catherine Lorgeoux, Pierre

Faure

\section{- To cite this version:}

Coralie Biache, Olivier Kouadio, Khalil Hanna, Catherine Lorgeoux, Pierre Faure. Role of goethite during air-oxidation of PAH-contaminated soils. Chemosphere, 2014, 117, pp.823-829. 10.1016/j.chemosphere.2014.11.004 . hal-01101620

\section{HAL Id: hal-01101620 https://hal-univ-rennes1.archives-ouvertes.fr/hal-01101620}

Submitted on 13 Jan 2015

HAL is a multi-disciplinary open access archive for the deposit and dissemination of scientific research documents, whether they are published or not. The documents may come from teaching and research institutions in France or abroad, or from public or private research centers.
L'archive ouverte pluridisciplinaire HAL, est destinée au dépôt et à la diffusion de documents scientifiques de niveau recherche, publiés ou non, émanant des établissements d'enseignement et de recherche français ou étrangers, des laboratoires publics ou privés. 


\section{Role of goethite during air-oxidation of PAH- contaminated soils}

Coralie Biache ${ }^{1.2, *}$, Olivier Kouadio ${ }^{1,2}$, Khalil Hanna $^{3}$ C Catherine Lorgeoux $^{4,5}$, Pierre Faure $^{1,2}$

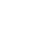

${ }^{1}$ Université de Lorraine, LIEC, UMR7360, Vandœuvre-lès-Nancy, F-54506, France (1) ${ }^{2}$ CNRS, LIEC, UMR7360, Vandœuvre-lès-Nancy, F-54506, France

${ }^{3}$ École Nationale Supérieure de Chimie de Rennes, UMR CNRS 6226, 11 Allée de Beaulieu, F-35708 Rennes Cedex 7, France.

${ }^{4}$ Université de Lorraine, GeoRessources, UMR7359, Vandœuvre-lès-Nancy, F-54506, France ${ }^{5}$ CNRS, GeoRessources, UMR7359, Vandœuvre-lès-Nancy, F-54506, France

* Corresponding author

Address: $\quad$ LIEC, Faculté des Sciences et Techniques

5

(6)

17

8

France

E-mail: coralie.biache@yahoo.fr (C. Biache)

Phone: (+33) 383684740 


\section{Abstract}

The impact of goethite on air-oxidation of PAH-contaminated soils was studied through two sets of experiments. (i) Soil extractable organic matter (EOM) and (ii) whole coking plant soils were oxidized at 60 and $100{ }^{\circ} \mathrm{C}$ for 160 days, with/without goethite. Organic matter $(\mathrm{OM})$ mineralization was monitored via $\mathrm{CO}_{2}$ production and polycyclic aromatic compounds (PACs) oxidation was investigated by GC-MS analyses. The decrease in EOM and PAH contents, and the oxygenated-PAC production observed during EOM oxidation, were enhanced by the presence of goethite. PACs were likely transformed at the goethite surface through electron transfer process. Mass carbon balance revealed a transfer from EOM to the insoluble organic fraction indicating condensation/polymerization of organics. Soil oxidation induced a decrease in EOM, PAH but also in oxygenated-PAC contents, underscoring different oxidation or polymerization behavior in soil. The goethite addition had a lesser impact suggesting that indigenous minerals played an important role in PAC oxidation.

Keywords: contaminated soil; polycyclic aromatic compound (PAC); oxygenated-PAC; goethite; oxidation 


\section{Introduction}

Iron oxides are the most abundant metallic oxides in soils (Schwertmann and Taylor, 1989), they are present in most soils and encompass oxides, oxyhydroxides and hydrated oxides. Feminerals are known to play an active part in the organic contamination fate as they represent strong sorption surfaces for pollutants and they catalyze many important redox transformations (Borch et al., 2009). During the past decades their ability to participate in such redox reactions was involved in remediation strategies for organic contamination. For instance Fe-minerals are associated with $\mathrm{H}_{2} \mathrm{O}_{2}$ to produce hydroxyl radicals that can degrade organic compounds in Fenton-like reactions. Soil iron minerals i.e. magnetite, hematite, goethite, and ferrihydrite, are all able to catalyze $\mathrm{H}_{2} \mathrm{O}_{2}$ (Yap et al., 2011).

Fenton-like reaction has been investigated for the remediation of water and soil contaminated with halogenated solvent, pesticides and petroleum hydrocarbons (Watts and Stanton, 1999; Usman et al., 2013). Fenton-like reaction shows also a great potential for polycyclic aromatic hydrocarbon (PAH, compounds constituted of two, or more, fused benzene rings) degradation in contaminated soils (Nam et al., 2001; Usman et al., 2012). The catalytic role of iron oxides for Fenton-like reaction is extensively studied for chemical remediation purpose. However such treatments are not automatically applied to contaminated soils and little is known about the involvement of iron oxide in processes occurring during natural attenuation of contaminated soils, especially abiotic oxidation. Some authors studied iron oxide-mediated oxidative transformations of organic compounds (Zhang and Huang, 2007; Lin et al., 2012) but the experiments were designed with solids suspended in aqueous solution which is not representative of real soil conditions. Wang et al. (2009) studied pyrene degradation on iron oxide under UV radiation and evidenced photocatalytic effect of several iron oxide. In real 
soils UV light affects only the surface layers since its intensity decays rapidly in the solid phase. Abiotic oxidation still occurs in deeper layer but so far this process was scarcely investigated, probably due to the difficulty to study this process independently to others. This difficulty can be bypassed using experimental simulation. Indeed low-temperature oxidations $\left(60-130{ }^{\circ} \mathrm{C}\right)$ are proven to successfully mimic long-term abiotic oxidation of fossil organic matter (OM) (Faure et al., 1999; Elie et al., 2000; Blanchart et al., 2012). Such experiments were extensively used in the 1980s to study coal weathering and its impact on coal heating properties (Gethner, 1987; Calemma et al., 1988; Jakab et al., 1988). More recently, lowtemperature oxidations of PAH-contaminated matrices showed that minerals (e.g. clay minerals and calcite) play an important role on the contamination fate (Ghislain et al., 2010; Biache et al., 2011; Biache et al., 2014). Indeed, oxidation causes a production of oxygenatedpolycyclic aromatic compounds (O-PACs: PAH with oxygenated moieties e.g. alcohol, ketone, aldehyde groups) and formation of an insoluble carbonaceous residue, supposedly through oxidative polymerization, leading to the contamination stabilization. PAHcontaminated soils often contain high proportion of iron oxide and other metal oxides (Biache et al., 2014), however their influence on PAC oxidation has never been investigated in such context.

Therefore, this study reported a first investigation on the role of iron oxide (goethite) on PAC fate (including PAHs and O-PACs) during abiotic air-oxidation of contaminated soils. Its aim was to determine which mechanisms were involved during this major process involved in natural attenuation. Goethite $(\alpha-\mathrm{FeOOH})$ was selected because it is one of the most thermodynamically stable and the most abundant iron (oxy)(hydr)oxide in natural environments (Schwertmann and Cornell, 2007).

Two sets of experiments were performed. The first one was conducted on extractable organic matter (EOM) previously isolated from PAC-contaminated soils. Afterwards, EOM was 
mixed with goethite or silica sand; the latter was used as inert support since its reactivity towards organic compounds is limited (Ghislain et al. 2010). The second experiment was performed directly on soils, raw or supplemented with goethite. These two sets allowed investigating two levels of increasing complexity by studying the influence of an iron oxide on the soil EOM, which could give more precise information on the involved mechanisms, and on the whole soil including indigenous minerals, which is more complex but also more realistic. Oxidations were performed at 60 and $100{ }^{\circ} \mathrm{C}$, the latter allowing more advanced oxidation and the first one representing an intermediate between $100{ }^{\circ} \mathrm{C}$ and field temperatures.

\section{Materials and Methods}

\subsection{Samples}

Soils were sampled at two former coking plant sites (Homécourt and Neuves-Maisons, France), then freeze-dried, sieved $(2 \mathrm{~mm})$ and crushed $(500 \mu \mathrm{m})$. EOM was recovered by extracting parts of the soils in Soxhlet apparatus $\left(\mathrm{CHCl}_{3}, 24 \mathrm{~h}\right)$, it contains PACs and other organics of various size, from macromolecules (asphaltenes) to mono-aromatic units. NeuvesMaisons and Homécourt EOMs were concentrated at 1.4 and $2.4 \mathrm{mg} / \mathrm{mL}$, respectively. Soils were also used directly or mixed with goethite.

\subsection{Minerals}

The silica sand was Fontainebleau sand (180-500 $\mu \mathrm{m}$, Carlo Erba) used as a non-reactive reference in the EOM experiment.

Goethite $(\alpha-\mathrm{FeOOH})$ was synthesized according to Schwertmann and Cornell (2007). Briefly, sample was prepared by air-oxidation of a hydrolyzed $\mathrm{FeSO}_{4}$ solution according to Prélot et al. (2003) (cf. supporting information). 
Minerals were washed with dichloromethane prior experiments to prevent organic contamination.

\subsection{Oxidation experiment}

EOMs and soils were mixed with minerals according to the following proportions: silica sand $(2 \mathrm{~g})$ and goethite $(0.5 \mathrm{~g})$ mixed with Homécourt $(47.1 \mathrm{mg})$ and Neuves-Maisons (48.7 mg) EOMs, Homécourt (2.5 g) and Neuves-Maisons (5 g) soils taken alone or mixed with goethite $(0.5 \mathrm{~g})$ (Table S1). Soils and minerals were placed in $100 \mathrm{~mL}$ glass bottles equipped with open caps and PTFE/silicone septa. EOM aliquots were added to the minerals to reach the mineral/EOM proportions specified in Table S1. Bottles were left open in a ventilated hood until complete evaporation of the solvent.

Two sample sets were prepared and placed in ovens at 60 and $100{ }^{\circ} \mathrm{C} . \mathrm{CO}_{2}$ released in the bottles was measured weekly by an infrared absorbance measurement $\left(\lambda=2325.6 \mathrm{~cm}^{-1}\right)$ with an infrared Binos analyzer. The measured $\mathrm{CO}_{2}$ was normalized to the initial sample total ovens and, after $\mathrm{CO}_{2}$ measurements, were stored at $-18{ }^{\circ} \mathrm{C}$ prior analyses. and volumes were adjusted to $20 \mathrm{~mL}$. For each sample, an EOM fraction $(3 \mathrm{~mL})$ was transferred to a pre-weighed bottle and the EOM content was determined after solvent evaporation. 
2.5. PAC quantification

An internal PAH standard mix of $\left[{ }^{2} \mathrm{H}_{8}\right]$ naphthalene, $\left[{ }^{2} \mathrm{H}_{10}\right]$ acenaphthene,

$142\left[{ }^{2} \mathrm{H}_{10}\right]$ phenanthrene, $\left[{ }^{2} \mathrm{H}_{12}\right]$ chrysene, $\left[{ }^{2} \mathrm{H}_{12}\right]$ perylene $(25 \mu \mathrm{L}$ at $16 \mu \mathrm{g} / \mathrm{mL}$, Cluzeau $)$ was added 143 to the EOM $(75 \mu \mathrm{L})$ before being injected in a gas chromatograph coupled with a mass 144 spectrometer (GC-MS). The GC-MS was previously internally calibrated with the internal 145 standards listed above for 16 PAHs plus 4 O-PACs (Table 1) at 6 concentrations $(0.5,1,2,4$, 1466 and $8 \mu \mathrm{g} / \mathrm{mL}$ ). The GC was a Shimadzu GC-2010 Plus, equipped with a silica-glass 147 capillary column DB-5MS $(60 \mathrm{~m} \times 0.25 \mathrm{~mm}$ i.d. $\times 0.1 \mu \mathrm{m}$ film thickness $)$ coupled with a 148 QP2010-Ultra (Shimadzu) MS in fullscan mode with a transfer line heated at $300{ }^{\circ} \mathrm{C}$. The 149 oven temperature program was as follow: $70{ }^{\circ} \mathrm{C}$ for $2 \mathrm{~min}$, from 70 to $130{ }^{\circ} \mathrm{C}$ at $15^{\circ} \mathrm{C} / \mathrm{min}$, 150 then from 130 to $315{ }^{\circ} \mathrm{C}$ at $3{ }^{\circ} \mathrm{C} / \mathrm{min}$ and then a 15 -min hold at $315{ }^{\circ} \mathrm{C}$. Helium was used as 151 carrier gas in constant flow mode $(1.4 \mathrm{~mL} / \mathrm{min})$.

152

153

154

155

156

157

158

159

160

161

162
2.6. TOC content

TOC contents were determined in soils and EOM/mineral mixtures with a total carbon analyser TOC-V CSH (Shimadzu) associated with a solid sample module SSM-5000A (Shimadzu).

\section{Results}

3.1. EOM/minerals mixture 3.1.1. $\mathrm{CO}_{2}$ production

For both samples, $\mathrm{CO}_{2}$ production of the $\mathrm{EOM} /$ mineral mixture followed the same trend (Figure 1a,b). The maximum production was observed for the EOM/goethite mixtures 
oxidized at $100{ }^{\circ} \mathrm{C}$ and reached about 6 and 5\%o of TOC for Homécourt and Neuves-Maisons, respectively. It was followed by the $\mathrm{CO}_{2}$ produced by the EOM/goethite mixture during the $60{ }^{\circ} \mathrm{C}$ oxidation. Smaller amount of $\mathrm{CO}_{2}$ were observed for the EOM/sand mixture oxidations.
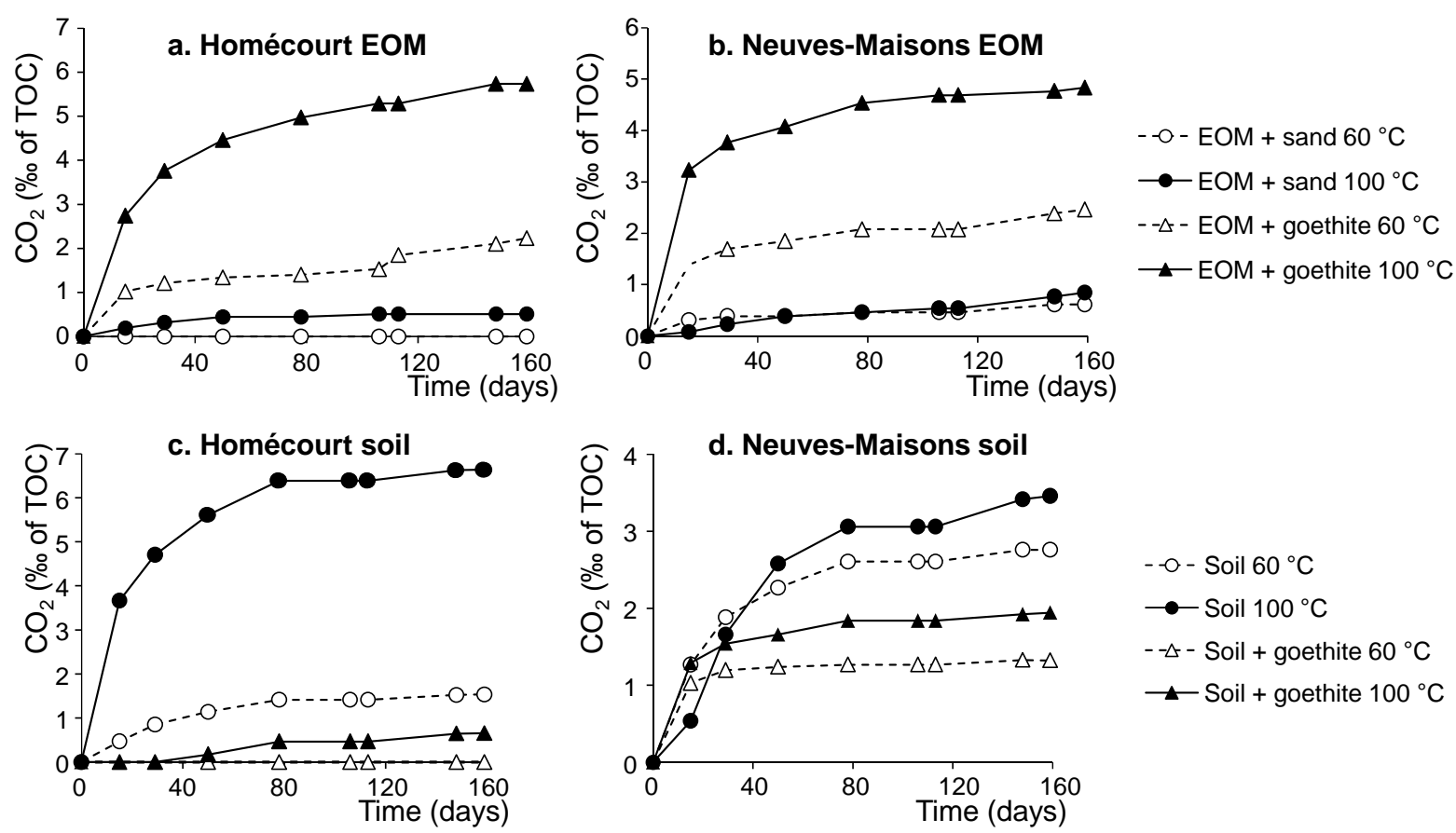

Figure 1: $\mathrm{CO}_{2}$ production during the 60 and $100^{\circ} \mathrm{C}$ oxidation experiments of the extractable organic matter (EOM) from (a.) Homécourt and (b.) Neuves-Maisons samples, mixed with silica sand and goethite, and (c.) Homécourt and (d.) Neuves-Maisons soils and soils mixed with goethite.

Overall, oxidations induced a decrease in the EOM content of the EOM/mineral mixtures

(Figure 2a). It was limited for the EOM/sand mixtures oxidized at $60{ }^{\circ} \mathrm{C}$ and was more important for the same mixture oxidized at $100{ }^{\circ} \mathrm{C}$ but clearly lower than the EOM/goethite mixtures. The decrease was similar for both Homécourt and Neuves-Maisons samples at 100 ${ }^{\circ} \mathrm{C}$ and went from 47.1 to $24.5 \mathrm{mg}$ and from 48.7 to $26.6 \mathrm{mg}$, respectively. 

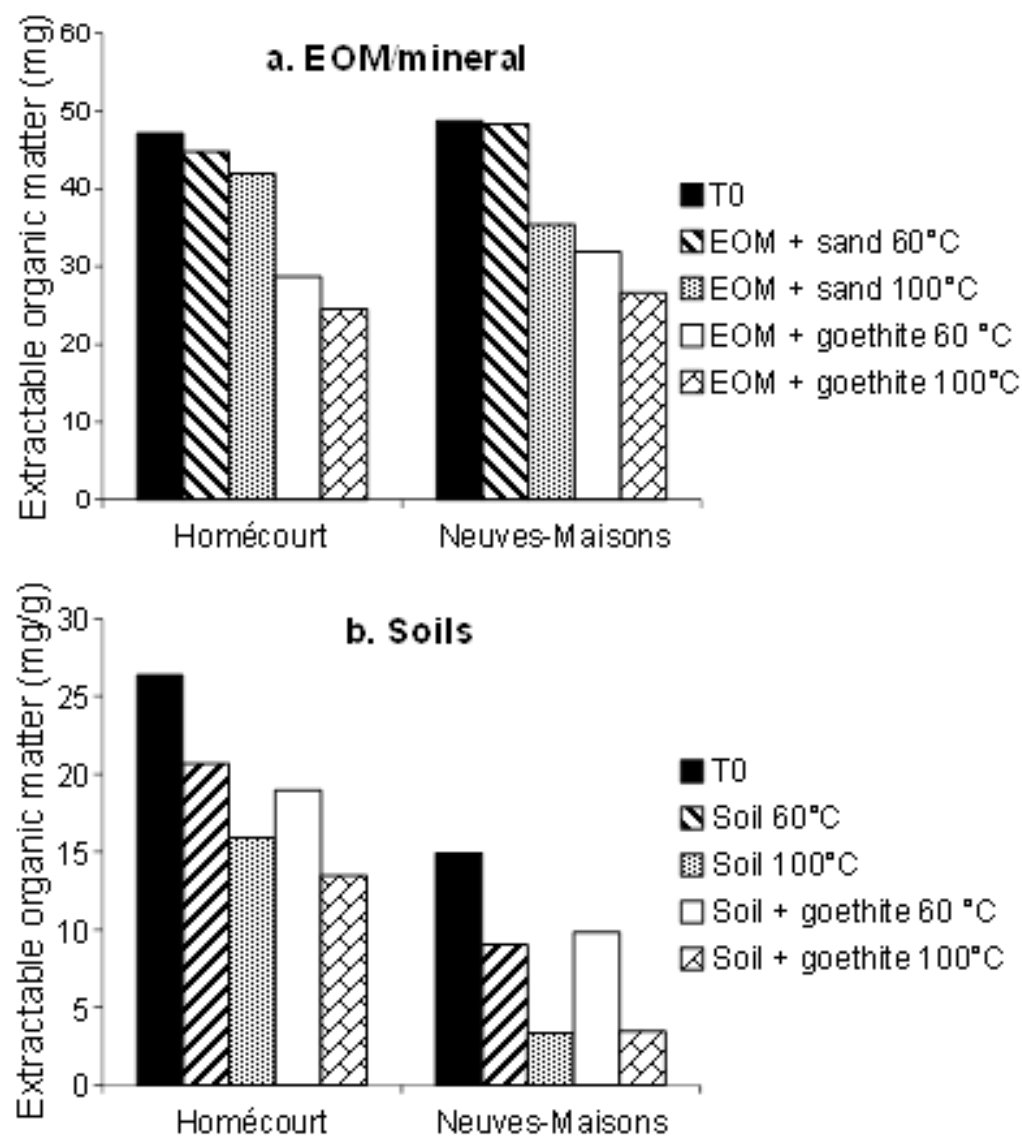

Figure 2: Extractable organic matter (EOM) contents after the 60 and the $100{ }^{\circ} \mathrm{C}$ oxidation experiment of (a.) Homécourt and Neuves-Maisons EOM/mineral mixtures, and (b.) Homécourt and Neuves-Maisons soil and soil/goethite mixtures.

Overall, EOM/mineral mixture oxidations induced a decrease in PAH concentrations. For Homécourt EOM/sand mixture it was limited to $5 \%$ after the $60{ }^{\circ} \mathrm{C}$ experiment (Table 1). It was more important at $100{ }^{\circ} \mathrm{C}(49 \%)$, mostly because of the loss of low molecular weight (LMW) compounds compared to high molecular weight (HMW), as shown by the respectively. It affected again mainly LMW PAHs, especially the 2- and 3-ring PAHs (Table 1, Figure S3). 
Contrary to the Homécourt EOM/sand mixture, PAHs decreased notably (40\%; Table 1) after the $60{ }^{\circ} \mathrm{C}$ oxidation of the Neuves-Maisons EOM/sand mixture. This decrease affected both LMW and HMW compounds (Table 1, Figure S4). It was confirmed by the LMW/HMW ratio which was barely modified (Table 1). At $100{ }^{\circ} \mathrm{C}$, the PAH decrease was more important and reached $61 \%$. The LMW PAH, especially the 2- and 3-ring compounds were more affected (Table 1, Figure S4). Neuves-Maisons EOM/goethite mixture oxidations induced also a decrease in the PAH contents. It was relatively close whatever the temperature $\left(63 \%\right.$ at $60{ }^{\circ} \mathrm{C}$ and $66 \%$ at $100{ }^{\circ} \mathrm{C}$; Table 1 )

\subsubsection{O-PAC contents}

Overall, oxidations induced an increase in the O-PAC contents (Table 1). For Homécourt EOM, it was more important at $60{ }^{\circ} \mathrm{C}$ than at $100{ }^{\circ} \mathrm{C}$. It was also higher when the EOM was mixed with goethite than when mixed with sand (Table 1). The O-PAC production concerned mostly 9-fluorenone and anthracene-9,10-dione (Table 1, Figure S5). The increase in O-PAC concentrations in Neuves-Maisons EOM/mineral mixtures was higher at $100{ }^{\circ} \mathrm{C}$ than at $60{ }^{\circ} \mathrm{C}$ (Table 1). The maximum O-PAC production reached 203\% when Neuves-Maisons EOM was mixed with goethite and oxidized at $100{ }^{\circ} \mathrm{C}$ (Table 1). This increase affected mostly benzo[de]anthracene-7-one and benz $[a]$ anthracene-7,12-dione (Table 1, Figure S6). 


\begin{tabular}{|c|c|c|c|c|c|c|c|c|c|c|}
\hline \multirow[b]{2}{*}{$\mu g / g$} & \multicolumn{5}{|c|}{ Homécourt } & \multicolumn{5}{|c|}{ Neuves-Maisons } \\
\hline & Initial & $\begin{array}{c}\mathrm{EOM} / \text { sand } \\
60^{\circ} \mathrm{C}\end{array}$ & $\begin{array}{c}\text { EOM/sand } \\
100^{\circ} \mathrm{C}\end{array}$ & $\begin{array}{c}\text { EOM/goet. } \\
60^{\circ} \mathrm{C}\end{array}$ & $\begin{array}{c}\text { EOM/goet. } \\
100^{\circ} \mathrm{C}\end{array}$ & Initial & $\begin{array}{c}\text { EOM/sand } \\
60^{\circ} \mathrm{C}\end{array}$ & $\begin{array}{c}\text { EOM/sand } \\
100^{\circ} \mathrm{C} \mathrm{C}\end{array}$ & $\begin{array}{c}\text { EOM/goet. } \\
60^{\circ} \mathrm{C}\end{array}$ & $\begin{array}{c}\text { EOM/goet } \\
100^{\circ} \mathrm{C}\end{array}$ \\
\hline Naphthalene & 17 & 2.0 & n.d. & n.d. & n.d. & 240 & 7.6 & n.d. & n.d. & n.d. \\
\hline Acenaphthylene & 290 & 250 & 160 & 160 & 93 & 170 & 99 & 26 & 49 & 24 \\
\hline Acenaphthene & 600 & 410 & n.d. & 61 & n.d. & 150 & 71 & n.d. & n.d. & n.d. \\
\hline Fluorene & 410 & 260 & 20 & 39 & 22 & 120 & 65 & 2.5 & 7.0 & 1.3 \\
\hline Phenanthrene & 750 & 760 & 150 & 720 & 320 & 390 & 270 & 21.1 & 130 & 34 \\
\hline Anthracene & 220 & 260 & 120 & 150 & 67 & 170 & 150 & 37 & 39 & 31 \\
\hline Fluoranthene & 400 & 550 & 300 & 560 & 260 & 550 & 440 & 220 & 320 & 220 \\
\hline Pyrene & 290 & 320 & 240 & 310 & 200 & 450 & 290 & 180 & 200 & 150 \\
\hline Benz $[a]$ anthracene & 190 & 150 & 140 & 140 & 46 & 480 & 290 & 220 & 160 & 160 \\
\hline Chrysene & 150 & 180 & 190 & 180 & 170 & 500 & 330 & 310 & 240 & 310 \\
\hline Benzo $[b]$ fluoranthene & 210 & 180 & 260 & 170 & 190 & 650 & 360 & 350 & 300 & 340 \\
\hline Benzo $[k]$ fluoranthene & 61 & 57 & 71 & 54 & 56 & 320 & 210 & 200 & 140 & 170 \\
\hline Benz $[a]$ pyrene & 140 & 130 & 39 & 94 & 4.9 & 500 & 290 & 110 & 150 & 0.6 \\
\hline Indeno $[c d]$ pyrene & 110 & 85 & 100 & 83 & 74 & 490 & 260 & 260 & 190 & 230 \\
\hline Dibenz $[a, h]$ anthracene & 34 & 63 & 69 & 68 & 44 & 170 & 81 & 110 & 58 & 92 \\
\hline Benzo[ghi]perylene & 84 & 120 & 140 & 110 & 89 & 370 & 210 & 200 & 160 & 190 \\
\hline Sum of PAHs & 3956 & 3777 & 1999 & 2899 & 1636 & 5720 & 3424 & 2247 & 2143 & 1953 \\
\hline PAH decrease $(\%)$ & & 5 & 49 & 27 & 59 & & 40 & 61 & 63 & 66 \\
\hline LMW/HMW & 3.1 & 2.9 & 1.0 & 2.2 & 1.4 & 0.6 & 0.7 & 0.3 & 0.5 & 0.3 \\
\hline 9-Fluorenone & 530 & 780 & 680 & 1500 & 1200 & 160 & 180 & 48 & 180 & 130 \\
\hline Anthracene-9,10-dione & 140 & 240 & 190 & 420 & 450 & 110 & 110 & 47 & 120 & 97 \\
\hline $\begin{array}{l}\text { Benzo[de]anthracene- } \\
\text { 7-one }\end{array}$ & 5.7 & 78 & n.d. & 82 & n.d. & 130 & 350 & 530 & 240 & 550 \\
\hline $\begin{array}{l}\text { Benz }[a] \text { anthracene- } \\
\text { 7,12-dione }\end{array}$ & n.d. & n.d. & 120 & 71 & n.d. & 64 & 130 & 430 & 150 & 630 \\
\hline Sum of O-PACs & 676 & 1098 & 990 & 2073 & 1650 & 464 & 770 & 1055 & 690 & 1407 \\
\hline O-PAC production $(\%)$ & & 62 & 46 & 207 & 144 & & 66 & 127 & 52 & 203 \\
\hline$\%$ O-PAC (/total PAC) & 15 & 23 & 33 & 42 & 50 & 8 & 18 & 32 & 24 & 42 \\
\hline
\end{tabular}

$212 \quad{ }^{\text {LLMW/HMW }}=$ ratio of sum of naphthalene to pyrene relative to sum of benzo[ $[a]$ anthracene to benzo[ghi]perylene 


\subsection{1. $\mathrm{CO}_{2}$ production}

For Homécourt soil, the $\mathrm{CO}_{2}$ production was higher when the raw soil was oxidized at $100{ }^{\circ} \mathrm{C}$ and reached 7\%o of the TOC at the end of the experiment (Figure 1c). The $\mathrm{CO}_{2}$ production was much lower at $60{ }^{\circ} \mathrm{C}$ and reached less than $2 \%$ of the TOC. It was followed by the Homécourt soil/goethite mixture oxidized at $100{ }^{\circ} \mathrm{C}$ whereas the same mixture produced nearly no $\mathrm{CO}_{2}$ at $60{ }^{\circ} \mathrm{C}$ (Figure 1c).

Similar pattern was observed for the Neuves-Maisons soil with a maximum $\mathrm{CO}_{2}$ production for the raw soil oxidized at $100{ }^{\circ} \mathrm{C}$ which reached about $4 \%$ of the TOC. However the differences between the modalities were less pronounced and the minimum $\mathrm{CO}_{2}$ production observed for the Neuves-Maisons/goethite mixture oxidized at $60{ }^{\circ} \mathrm{C}$ reached $1.3 \%$ of the TOC (Figure 1d).

It should be noted that a part of the generated gas could result from $\mathrm{CO}_{2}$ desorption from soil solid surfaces (e.g. minerals, OM) over the soil thermal treatments, but this process may be insignificant under our experimental conditions (Sumner, 2000).

\subsubsection{EOM contents}

Soil oxidations led to a decrease in the EOM contents (Figure 2b). For both soils and soil/goethite mixtures, it was more important at $100{ }^{\circ} \mathrm{C}$ than at $60{ }^{\circ} \mathrm{C}$. This decrease was enhanced by the presence of goethite in the case of Homécourt samples for which the EOM went from 26.4 to 19.0 and to $13.5 \mathrm{mg} / \mathrm{g}$ of soil after the 60 and the $100^{\circ} \mathrm{C}$ experiments, respectively. Surprisingly, no difference was observed with goethite addition to the NeuvesMaisons soil (Figure 2b).

\subsubsection{PAH contents}


Oxidations induced a strong decrease in the PAH concentrations for both soils. It was more important at 100 than at $60{ }^{\circ} \mathrm{C}$ and was maximum when goethite was added to the soil $(92 \%$ of decrease for both samples; Table 2). For both samples, the $60{ }^{\circ} \mathrm{C}$ experiments affected slightly more HMW than LMW compounds, as shown by the increasing LMW/HMW ratios (Table 2). On the contrary, the $100{ }^{\circ} \mathrm{C}$ experiment induced a decrease in this ratio, indicating a preferential loss of the LMW PAHs (Table 2, Figures S7 and S8).

243 Overall, the soil and soil/goethite mixture oxidations induced a decrease in the O-PAC contents. For the raw Homécourt soils, it was limited to $3 \%$ after the $100{ }^{\circ} \mathrm{C}$ experiment and reached $12 \%$ after the $60{ }^{\circ} \mathrm{C}$ oxidation. This decrease was higher when Homécourt soil was 246 mixed with goethite and attained $18 \%$ and $41 \%$ after the 60 and the $100{ }^{\circ} \mathrm{C}$ experiments, 247 respectively (Table 2, Figure S9).

248 The abatement rates were higher for the Neuves-Maisons soil with 54\% and $60 \%$ after the 60 249 and the $100{ }^{\circ} \mathrm{C}$ experiment on the raw soil, respectively. Goethite supplementation also 250 enhanced this decrease but the proportion of O-PAC abatement was similar for both 251 temperatures (71\%; Table 2, Figure S10). 


\begin{tabular}{|c|c|c|c|c|c|c|c|c|c|c|}
\hline \multirow[b]{2}{*}{$\mu g / g$} & \multicolumn{5}{|c|}{ Homécourt } & \multicolumn{5}{|c|}{ Neuves-Maisons } \\
\hline & Initial & $\begin{array}{l}\text { Soil } \\
60^{\circ} \mathrm{C}\end{array}$ & $\begin{array}{c}\text { Soil } \\
100^{\circ} \mathrm{C}\end{array}$ & $\begin{array}{c}\text { Soil/goet. } \\
60^{\circ} \mathrm{C}\end{array}$ & $\begin{array}{c}\text { Soil/goet. } \\
100^{\circ} \mathrm{C}\end{array}$ & Initial & $\begin{array}{c}\text { Soil } \\
60^{\circ} \mathrm{C}\end{array}$ & $\begin{array}{c}\text { Soil } \\
100^{\circ} \mathrm{C} \mathrm{C}\end{array}$ & $\begin{array}{c}\text { Soil/goet. } \\
60^{\circ} \mathrm{C}\end{array}$ & $\begin{array}{c}\text { Soil/goet. } \\
100^{\circ} \mathrm{C}\end{array}$ \\
\hline Naphthalene & 9.4 & 4.5 & 0.3 & 3.6 & n.d. & 74 & 26 & 3.6 & 12 & n.d. \\
\hline Acenaphthylene & 160 & 65 & 48 & 57 & 40 & 52 & 15 & 4.0 & 13 & 4.0 \\
\hline Acenaphthene & 340 & 18 & n.d. & 13 & n.d. & 46 & 2.0 & n.d. & 1.6 & n.d. \\
\hline Fluorene & 230 & 26 & 13 & 22 & 9.1 & 36 & 2.4 & 0.3 & 1.9 & 0.2 \\
\hline Phenanthrene & 420 & 240 & 140 & 200 & 14 & 120 & 47 & 19 & 28 & 6.3 \\
\hline Anthracene & 130 & 47 & 24 & 40 & 21 & 52 & 18 & 3.3 & 10 & 2.9 \\
\hline Fluoranthene & 220 & 120 & 68 & 120 & 15 & 170 & 94 & 33 & 73 & 17 \\
\hline Pyrene & 160 & 73 & 26 & 61 & n.d. & 140 & 68 & 11 & 44 & n.d. \\
\hline Benz $[a]$ anthracene & 110 & 32 & 15 & 20 & 3.6 & 150 & 55 & 10 & 22 & 1.7 \\
\hline Chrysene & 81 & 34 & 25 & 31 & 6 & 150 & 57 & 33 & 45 & 15 \\
\hline Benzo $[b]$ fluoranthene & 120 & 37 & 39 & 38 & 23 & 200 & 81 & 53 & 75 & 42 \\
\hline Benzo $[k]$ fluoranthene & 34 & 13 & 9.5 & 12 & 5.3 & 97 & 27 & 15 & 25 & 9.0 \\
\hline Benz $[a]$ pyrene & 77 & 22 & 6.4 & 18 & 5.0 & 150 & 31 & 2.3 & 15 & 0.9 \\
\hline Indeno $[c d]$ pyrene & 61 & 14 & 17 & 14 & 14 & 150 & 39 & 23 & 33 & 20 \\
\hline Dibenz $[a, h]$ anthracene & 19 & 4.5 & 4.9 & 4.2 & 3.0 & 52 & 10 & 7.6 & n.d. & 5.3 \\
\hline Benzo[ghi]perylene & 47 & 12 & 13 & 12 & 11 & 120 & 32 & 17 & 28 & 15 \\
\hline Sum of PAHs & 2218 & 762 & 449 & 666 & 170 & 1759 & 604 & 235 & 427 & 139 \\
\hline PAH decrease (\%) & & 66 & 80 & 70 & 92 & & 66 & 87 & 76 & 92 \\
\hline LMW/HMW & 3.1 & 3.5 & 2.4 & 3.5 & 1.4 & 0.6 & 0.8 & 0.5 & 0.8 & 0.3 \\
\hline 9-Fluorenone & 300 & 270 & 280 & 250 & 170 & 48 & 34 & 22 & 18 & 14 \\
\hline Anthracene-9,10-dione & 72 & 50 & 60 & 45 & 40 & 33 & 17 & 11 & 11 & 7.9 \\
\hline Benzo[de]anthracene- & & & & & & & & & & \\
\hline 7-one & 3.2 & 5.0 & n.d. & 5.0 & n.d. & 39 & 6.5 & 4.2 & 4.9 & n.d. \\
\hline Benz $[a]$ anthracene- & & & & & & & & & & \\
\hline 7,12-dione & n.d. & 5.5 & 22 & 5.9 & 11 & 20 & 6.3 & 19 & 5.8 & 18 \\
\hline Sum of O-PACs & 375 & 331 & 362 & 306 & 221 & 140 & 64 & 56 & 40 & 40 \\
\hline O-PAC decrease $(\%)$ & & 12 & 3 & 18 & 41 & & 54 & 60 & 71 & 71 \\
\hline$\%$ O-PAC (/total PAC) & 14 & 30 & 45 & 31 & 57 & 7 & 10 & 19 & 9 & 22 \\
\hline
\end{tabular}

${ }^{\mathrm{a}} \mathrm{LMW} / \mathrm{HMW}=$ ratio of sum of naphthalene to pyrene relative to sum of benzo[ $[a]$ anthracene to benzo $[\mathrm{ghi}]$ perylene 


\section{Discussion}

Overall, goethite showed a high reactivity during the EOM oxidation as $\mathrm{CO}_{2}$ production and the PAH degradation rate were enhanced by its presence. However, it should be noted that the mineralization was of less importance because the amount of produced $\mathrm{CO}_{2}$ during the experiment remained very low $(<7 \%$ of TOC).

To give a better insight into the main process involved in the reduction of the PAH and EOM contents, a carbon mass balance was performed (Figure 3). It showed that most of the carbon from the initial EOM was transferred to the insoluble compartment. Such observations were made in previous studies (Ghislain et al., 2010; Biache et al., 2011; Biache et al., 2014) where air-oxidation of PAH associated with active minerals led to the decrease in EOM content and to the formation of an insoluble carbonaceous residue resulting from oxidation-induced polymerization.
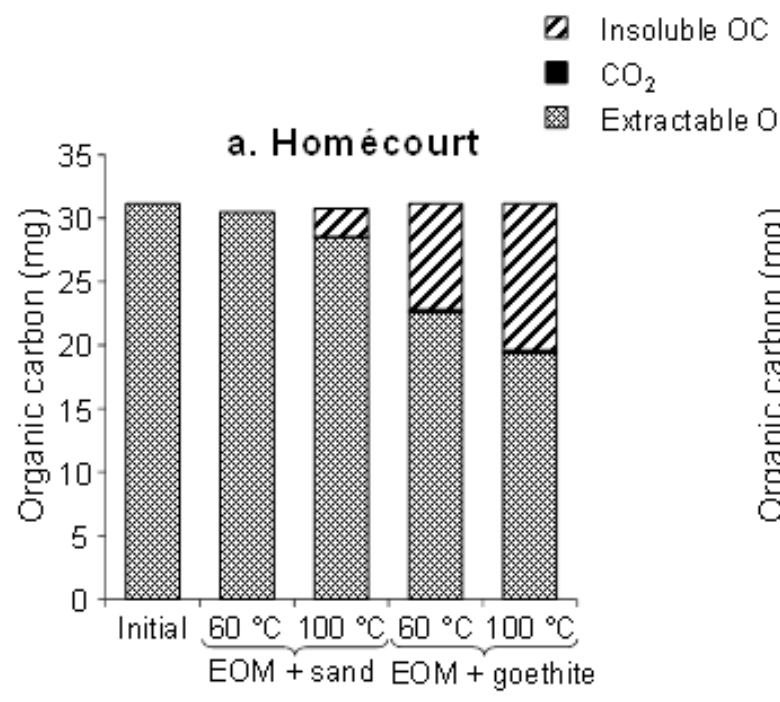

圆 Extractable OC

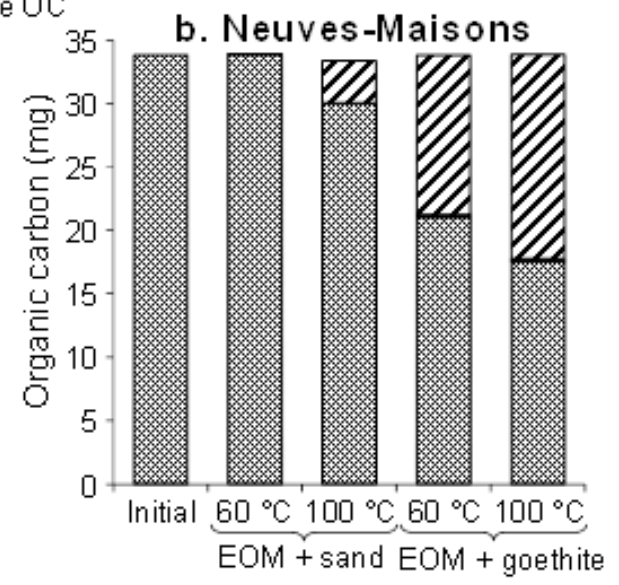


EOM oxidations also induced an O-PAC production (ketones). Such compounds are known to be produced during PAH oxidation in various contexts i.e. chemical oxidation (Lundstedt et al., 2006), photo-degradation (Barbas et al., 1996) and biodegradation (Kazunga and Aitken, 2000). As the O-PAC production was much more important in the EOM/goethite mixture than in the EOM/sand mixture, goethite seems to play an active part in the oxidation process. The oxidation of organic compounds on goethite is known to be initiated by the sorption and then formation of inner-sphere surface complexes with Fe ${ }^{\mathrm{III}}$ surface sites (Pizzigallo et al., 1998). This chemical coordination at the goethite surface is a prerequisite for the electron transfer process (Stone and Morgan, 1987). Indeed, the sorbed molecule transfers an electron to $\mathrm{Fe}^{\mathrm{III}}$ site at goethite surfaces, leading to the formation of a very reactive cation radical that in turn interacts with oxygen to produce oxygenated species (McBride, 1987). Finally, dissociation of surface complexes and release of oxygenated species may occur, while the newly generated $\mathrm{Fe}^{\mathrm{II}}$ may be rapidly oxidized by $\mathrm{O}_{2}$. Such mechanism was suggested for room temperature oxidation of organic compounds by $\mathrm{Mn}^{\mathrm{VI}}-\mathrm{Mn}^{\mathrm{III}}$-oxides and $\mathrm{Fe}^{\mathrm{III}}$-oxides (McBride, 1987; Stone and Morgan, 1987).

Our observations, i.e. important decrease in PAH contents and important production of OPACs, were consistent with the previously mentioned mechanism. This oxidation mechanism must be favored by the increasing temperature, since more decay in EOM and PAH contents and more O-PAC production were noted at 100 than at $60^{\circ} \mathrm{C}$. Generally, the electron transfer process induced by chemical complexation is considered as endothermic and therefore improved by increasing temperature (Chidsey, 1991).

Moreover, several studies dealing with the $\mathrm{Fe}^{\mathrm{III}}-$ or $\mathrm{Mn}^{\mathrm{III} / \mathrm{IV}}$-induced oxidation of aromatic compounds have pointed out same polymerization/condensation process as observed in this study (Li et al., 2003; Arroyo et al., 2005; Russo et al., 2005). 
4.2. Impact of goethite addition on the soil contamination.

297

When comparing the PAH decrease rates of both experiments (EOMs and soils), whole soils

seemed to be more reactive. Goethite addition had a different impact on the whole soil vs the isolated EOM. While more decay in PAH concentration was observed in the presence of goethite, less $\mathrm{CO}_{2}$ was produced and O-PAC concentrations decreased. The EOM content did not change significantly compared to the soil without goethite. The first explanation for these differences is the presence in the soils of other -mineral and organic- reactive surfaces. Previous studies dealing with biotic and abiotic oxidation of PAH contaminated matrices have already pointed out a high reactivity of complex soil systems (Biache et al., 2011; Biache et al., 2013; Biache et al., 2014) which has been attributed to the presence of reactive phases such as clay minerals, metal oxides and organic macromolecules. Both soils contain such reactive minerals (Biache et al., 2014), which may explain why the decrease in PAH and EOM contents were already high in the soil without goethite addition. Similar mechanisms of PAH oxidation could be involved here as in the EOM experiment but other by-products may be formed. The decrease in O-PAC contents may be explained by a strong sorption/sequestration in the soil and/or incorporation in the macromolecular network via polymerization. The high decay of EOM in the whole soil compared to the EOM/mineral mixture tends to support this hypothesis.

The goethite major impact was to reduce the $\mathrm{CO}_{2}$ production in the whole soil experiment even if the $\mathrm{CO}_{2}$ amount remained very low in all investigated experiments (less than $7 \%$ and 4\%o of the Homécourt and Neuves-Maisons soils, respectively). This slight discrepancy "soil vs soil/goethite" might be due to $\mathrm{CO}_{2}$ adsorption on goethite surfaces, but this process cannot be quantitatively evaluated in soil complex systems (Russell et al., 1975). 


\subsection{Impact of initial soil composition on the OM reactivity}

321

While both EOMs exhibited similar global trends during oxidations, some molecular-level differences can be observed. For example during the mineral/EOM oxidation, O-PAC compounds were produced for both EOMs; however the distribution of the generated compounds was different (Table 1, Figures S5 and S6). Indeed, the main O-PACs produced during Homécourt EOM oxidation were 3-ring O-PACs (9-fluorenone and anthracene-9,10dione) whereas for Neuves-Maisons EOM oxidation, 4-ring O-PACs (benzo[de]anthracene-7one and benz $[a]$ anthracene-7,12-dione) were predominantly generated. These discrepancies can be attributed to differences in the initial PAH soil composition; Homécourt sample being dominated by 3-ring PAHs (Table 1, Figure S3) and Neuves-Maisons being dominated by 4and 5-ring PAHs (Table 1, Figure S4). It is worthwhile noting that PAHs are known to be precursors of O-PAC formation. For instance 9-fluorenone is known to be one of the oxidation product of fluorene (Lee et al., 2001) which occurs in high concentration in Homécourt sample and, similarly, benz[a]anthracene-7,12-dione can be generated during benz $[a]$ anthracene oxidation (Lee et al., 2001) which is one of the major PAHs of NeuvesMaisons sample.

Difference of the initial sample composition also seems to influence the sample response to oxidation. For both EOM/mineral and soil oxidations, the decrease in EOM contents was more important for Neuves-Maisons samples than for Homécourt (Figure 2). As discussed, this decrease was a transfer of the organic carbon from the EOM to the insoluble fraction which was more important for Neuves-Maisons than for Homécourt (Figure 3). The latter observation can be due to the fact that Neuves-Maisons sample presented higher proportion of 
HMW compounds than Homécourt and HMW compounds are more inclined to be stabilized (condensed) in the non-extractable fraction (Northcott and Jones, 2001).

\section{Summary and conclusion}

In all experiments, oxidation led to (i) a decrease in PAH concentrations, (ii) a low production of $\mathrm{CO}_{2}$ and (iii) a decrease in EOM content due to a condensation/polymerization phenomenon evidenced by a carbon mass balance. Oxidation of the EOM/minerals also led to a production of O-PACs, the initial PAH soil composition governing the type of generated compounds. The oxidation effects were more pronounced for EOM/goethite mixture than for EOM/silica sand mixture. These observations are consistent with the famous goethite-induced transformation mechanism of organic compounds. After PAC sorption on goethite surfaces, electron transfer process occurs leading to the formation of reactive cation radical that in turn interacts with oxygen or oxygen-species yielding oxidized products.

As in EOM experiments, goethite addition to the whole soils affected OM oxidation, but in a lesser extent. This limited effect was likely due to the presence of a significant amount of reactive phases naturally occurring in the soils. The soil initial composition also impacted its evolution during oxidation; higher abundance of HMW compounds favoring the formation of an insoluble residue and therefore EOM stabilization.

These conclusions showed that goethite may play a part in natural attenuation of PAH contaminated soils as it contributes to contamination stabilization during low-temperature airoxidation. This work provides first results of the mechanisms involved and also underlined the potential of indigenous reactive minerals to stabilize organic contamination. Therefore their impact on the fate and transformation of PAHs in soils under different conditions (humidity, temperature, oxygen concentrations) more representative of the field should be 
investigated, and the long-term behavior of the refractory compounds generated during oxidation (e.g. insoluble carbonaceous residues) should be explored.

\section{Acknowledgements}

We thank the GISFI (French Scientific Interest Group - Industrial Wasteland (http://www.gisfi.prd.fr). We thank Pr. Christian Ruby from the LCPME laboratory (Nancy) for supplying us with the goethite.

\section{References}

Arroyo, L.J., Li, H., Teppen, B.J., Johnston, C.T., Boyd, S.A., 2005. Oxidation of 1-naphthol coupled to reduction of structural $\mathrm{Fe}^{3+}$ in smectite. Clays Clay Miner. 53, 587-596.

Barbas, J.T., Sigman, M.E., Dabestani, R., 1996. Photochemical oxidation of phenanthrene sorbed on silica gel. Environ. Sci. Technol. 30, 1776-1780.

Biache, C., Faure, P., Mansuy-Huault, L., Cébron, A., Beguiristain, T., Leyval, C., 2013. Biodegradation of the organic matter in a coking plant soil and its main constituents. Org. Geochem. 56, 10-18.

Biache, C., Ghislain, T., Faure, P., Mansuy-Huault, L., 2011. Low temperature oxidation of a coking plant soil organic matter and its major constituents: An experimental approach to simulate a long term evolution. J. Hazard. Mater. 188, 221-230.

Biache, C., Kouadio, O., Lorgeoux, C., Faure, P., 2014. Impact of clay mineral on air oxidation of PAH-contaminated soils. Environ Sci Pollut Res, 1-10.

Blanchart, P., Faure, P., Bruggeman, C., De Craen, M., Michels, R., 2012. In situ and laboratory investigation of the alteration of Boom Clay (Oligocene) at the air- 
geological barrier interface within the Mol underground facility (Belgium): Consequences on kerogen and bitumen compositions. Appl. Geochem. 27, 2476-2485.

Borch, T., Kretzschmar, R., Kappler, A., Cappellen, P.V., Ginder-Vogel, M., Voegelin, A., Campbell, K., 2009. Biogeochemical redox processes and their impact on contaminant dynamics. Environ. Sci. Technol. 44, 15-23.

Calemma, V., Rausa, R., Margarit, R., Girardi, E., 1988. FT-i.r. study of coal oxidation at low temperature. Fuel 67, 764-770.

Chidsey, C.E.D., 1991. Free energy and temperature dependence of electron transfer at the metal-electrolyte Interface. Science 251, 919-922.

Elie, M., Faure, P., Michels, R., Landais, P., Griffault, L., 2000. Natural and laboratory oxidation of low-organic-carbon-content sediments: comparison of chemical changes in hydrocarbons. Energy Fuels 14, 854-861.

Faure, P., Landais, P., Griffault, L., 1999. Behavior of organic matter from Callovian shales during low-temperature air oxidation. Fuel 78, 1515-1525.

Gethner, J.S., 1987. Kinetic study of the oxidation of Illinois No. 6 coal at low temperatures: Evidence for simultaneous reactions. Fuel 66, 1091-1096.

Ghislain, T., Faure, P., Biache, C., Michels, R., 2010. Low-temperature, mineral-catalyzed air oxidation: a possible new pathway for PAH stabilization in sediments and soils. Environ. Sci. Technol. 44, 8547-8552.

Jakab, E., Hoesterey, B., Windig, W., Hill, G.R., Meuzelaar, H.L.C., 1988. Effects of low temperature air oxidation (weathering) reactions on the pyrolysis mass spectra of US coals. Fuel 67, 73-79.

Kazunga, C., Aitken, M.D., 2000. Products from the incomplete metabolism of pyrene by polycyclic aromatic hydrocarbon-degrading bacteria. Appl. Environ. Microbiol. 66, 1917-1922. 
Lee, B.-D., Iso, M., Hosomi, M., 2001. Prediction of Fenton oxidation positions in polycyclic aromatic hydrocarbons by Frontier electron density. Chemosphere 42, 431-435.

Li, H., Lee, L.S., Schulze, D.G., Guest, C.A., 2003. Role of soil manganese in the oxidation of aromatic amines. Environ. Sci. Technol. 37, 2686-2693.

Lin, K., Ding, J., Wang, H., Huang, X., Gan, J., 2012. Goethite-mediated transformation of bisphenol A. Chemosphere 89, 789-795.

Lundstedt, S., Persson, Y., Öberg, L., 2006. Transformation of PAHs during ethanol-Fenton treatment of an aged gasworks' soil. Chemosphere 65, 1288-1294.

McBride, M.B., 1987. Adsorption and oxidation of phenolic compounds by iron and manganese oxides. Soil Sci. Soc. Am. J. 51, 1466-1472.

Nam, K., Rodriguez, W., Kukor, J.J., 2001. Enhanced degradation of polycyclic aromatic hydrocarbons by biodegradation combined with a modified Fenton reaction. Chemosphere 45, 11-20.

Northcott, G.L., Jones, K.C., 2001. Partitioning, extractability, and formation of nonextractable PAH residues in soil. 1. Compound Differences in Aging and Sequestration. Environ. Sci. Technol. 35, 1103-1110.

Pizzigallo, M.D.R., Ruggiero, P., Crecchio, C., Mascolo, G., 1998. Oxidation of chloroanilines at metal oxide surfaces. J. Agr. Food Chem. 46, 2049-2054.

Prélot, B., Villiéras, F., Pelletier, M., Gérard, G., Gaboriaud, F., Ehrhardt, J.-J., Perrone, J., Fedoroff, M., Jeanjean, J., Lefèvre, G., Mazerolles, L., Pastol, J.-L., Rouchaud, J.-C., Lindecker, C., 2003. Morphology and surface heterogeneities in synthetic goethites. J. Colloid Interface Sci. 261, 244-254.

Russell, J.D., Paterson, E., Fraser, A.R., Farmer, V.C., 1975. Adsorption of carbon dioxide on goethite $(\alpha-\mathrm{FeOOH})$ surfaces, and its implications for anion adsorption. J. Chem. Soc., Faraday Trans. 71, 1623-1630. 
Russo, F., Rao, M., Gianfreda, L., 2005. Bioavailability of phenanthrene in the presence of birnessite-mediated catechol polymers. Appl. Microbiol. Biotechnol. 68, 131-139.

Schwertmann, U., Cornell, R.M., 2007. Goethite. in Iron oxides in the laboratory $2^{\text {nd }}$ Ed. Wiley-VCH Verlag GmbH, pp. 67-92.

Schwertmann, U., Taylor, R.M., 1989. Iron Oxides. in: Dixon, J.B., Weed, S.B. (Eds.). Minerals in soil environments. Soil Science Society of America, pp. 379-438.

Stone, A.T., Morgan, J.J., 1987. Reductive dissolution of metal oxides. in: Aquatic surface chemistry: chemical processes at the particle-water interface. John Wiley and Sons, New York. 1987. p 221-254.

Sumner, M.E. (Ed.), 2000. Handbook of soil science. CRC Press LLC.

Usman, M., Faure, P., Lorgeoux, C., Ruby, C., Hanna, K., 2013. Treatment of hydrocarbon contamination under flow through conditions by using magnetite catalyzed chemical oxidation. Environ Sci Pollut Res 20, 22-30.

Usman, M., Faure, P., Ruby, C., Hanna, K., 2012. Remediation of PAH-contaminated soils by magnetite catalyzed Fenton-like oxidation. Appl. Catal., B 117-118, 10-17.

Wang, Y., Liu, C.S., Li, F.B., Liu, C.P., Liang, J.B., 2009. Photodegradation of polycyclic aromatic hydrocarbon pyrene by iron oxide in solid phase. J. Hazard. Mater. 162, 716723.

Watts, R.J., Stanton, P.C., 1999. Mineralization of sorbed and NAPL-phase hexadecane by catalyzed hydrogen peroxide. Water Res. 33, 1405-1414.

Yap, C.L., Gan, S., Ng, H.K., 2011. Fenton based remediation of polycyclic aromatic hydrocarbons-contaminated soils. Chemosphere 83, 1414-1430.

Zhang, H., Huang, C.-H., 2007. Adsorption and oxidation of fluoroquinolone antibacterial agents and structurally related amines with goethite. Chemosphere 66, 1502-1512. 